Псарьова Ольга Анатоліївна аспірант кафедри проектного менеджменту, Одеський регіональний інститут державного управління Національної академії державного управління при Президентові України, вул. Генуезька, 22, м. Одеса, 65000, тел.: (044) 481-21-55, e-mail: helgabeautys@gmail.com, https://orcid.org/0000-0003-0082-1776

\title{
ДЕРЖАВНИЙ МЕХАНІЗМ РЕГУЛЮВАННЯ ТРАНСПЛАНТОЛОГІЇ В УКРАЇНІ, СВІТОВІ ТЕНДЕНЦІЇ ТА ВІТЧИЗНЯНІ ПРІОРИТЕТИ РОЗВИТКУ
}

Анотація. В епоху глобалізаційних викликів рівень здоров'я населення знижується, відповідальність за своє власне здоров'я ще впроваджується у свідомість громадян. Охорона здоров'я - один з основних напрямків державної політики і відповідає національним інтересам держави. Актуальність теми трансплантології в Україні в останні роки зростає. Трансплантація за межами нашої держави, як подорож у розрізі виїзного медичного туризму, у зв'язку з епідемією захворювання COVID - 19, 3 змінами правил відвідування і пересування до інших країн, стала досить складною процедурою, хоча туризм 3 лікувальною, діагностичною, оздоровчою метою у світі - це світова прибуткова та динамічна галузь. Транскордонний медичний туризм іноді взагалі стає неможливим, але спостерігається розвиток в межах держави, тобто розвивається внутрішній туризм, що в свою чергу, призводить до розвитку необхідних напрямів та реформувань в сфері охорони здоров'я, в трансплантології також. Заклади охорони здоров'я України отримали фінансування на законодавчому рівні, що в свою чергу дає можливість для розвитку надання послуг 3 трансплантації. У статті досліджено і виявлено недоліки правового регулювання органної трансплантології, як одного з напрямків медичної галузі, що, на жаль, гальмує розвиток медичного туризму. «Законодавство України про трансплантацію базується на Конституції України та складається з Основ законодавства України про охорону здоров'я, інших законодавчих актів, що регулюють відносини з питань, пов'язаних з охороною здоров'я, цього Закону та інших прийнятих відповідно до них нормативно-правових актів. Якщо міжнародним договором України, згода на обов'язковість якого надана Верховною Радою України, встановлені інші норми, ніж ті, що передбачені цим Законом, застосовуються норми міжнародного договору. Державна політика у 
сфері застосування трансплантації та здійснення діяльності, пов’язаної 3 трансплантацією, спрямовується на: надання доступної та якісної медичної допомоги iз застосуванням трансплантації відповідно до цього Закону; забезпечення безоплатності надання медичної допомоги із застосуванням трансплантації; додержання прав людини та захист людської гідності при застосуванні трансплантації та здійснення діяльності, пов'язаної 3 трансплантацією, у порядку, встановленому цим Законом та іншими законами України; забезпечення належної якості і безпеки анатомічних матеріалів на усіх етапах трансплантації та здійснення діяльності, пов'язаної 3 трансплантацією; забезпечення дотримання основних принципів застосування трансплантації; запобігання незаконному використанню анатомічних матеріалів людини; координацію діяльності органів виконавчої влади у сфері застосування трансплантації та здійснення діяльності, пов’язаної з трансплантацією; створення умов для проведення наукових досліджень, впровадження нових технологій щодо застосування трансплантації та здійснення діяльності, пов’язаної 3 трансплантацією; розвиток міжнародного співробітництва у цій сфері. Формування та реалізацію державної політики у сфері застосування трансплантації та здійснення діяльності, пов'язаної з трансплантацією, у межах своїх повноважень забезпечують Кабінет Міністрів України, центральні та місцеві органи виконавчої влади» [3]. Подальший розвиток трансплантології, реформа в цієї галузі з ефективними змінами, впровадження міжнародних кращих практик, потребує підтримки на загальнодержавному рівні.

Ключові слова: державне регулювання, медичний туризм, правове регулювання, трансплантологія.

Psarova Olha Anatoliivna PhD-student Project Management Department, Odesa Regional Institute of Public Administration of the National Academy of Public Administration under the President of Ukraine, Genuezka St., 22, Odesa, 65000, tel.: (044) 481-21-55, e-mail: helgabeautys@gmail.com, https://orcid.org/0000-0003-0082-1776

\section{STATE MECHANISM OF REGULATION OF TRANSPLANTOLOGY IN UKRAINE, WORLD TRENDS AND DOMESTIC DEVELOPMENT PRIORITIES}

Abstract. In the age of globalization challenges, the level of health of the population is declining, the responsibility for their own health is still being introduced into the minds of citizens. Health care is one of the main directions of state policy and meets the national interests of the state. The relevance of the topic of transplantation in Ukraine in recent years is growing. Transplantation outside our country, as a trip in 
terms of outbound medical tourism, in connection with the epidemic of COVID - 19, with changes in the rules of visiting and moving to other countries, has become quite a complex procedure, although tourism for medical, diagnostic, health purposes in the world is a profitable and dynamic industry. Cross-border medical tourism sometimes becomes impossible at all, but there is a development within the state, ie domestic tourism is developing, which in turn leads to the development of the necessary directions and reforms in the field of health care, in transplantation as well. Healthcare facilities in Ukraine have received funding at the legislative level, which in turn provides an opportunity to develop the provision of transplant services. The article examines and identifies the shortcomings of the legal regulation of organ transplantation as one of the areas of the medical field, which, unfortunately, inhibits the development of medical tourism. "The legislation of Ukraine on transplantation is based on the Constitution of Ukraine and consists of the Fundamentals of the legislation of Ukraine on health care, other legislative acts regulating relations on issues related to health care, this Law and other regulations adopted in accordance with them. legal acts. If an international treaty of Ukraine, the binding nature of which has been approved by the Verkhovna Rada of Ukraine, establishes norms other than those provided for by this Law, the norms of the international treaty shall apply. State policy in the field of transplantation and transplantation activities is aimed at: providing affordable and high-quality medical care with transplantation in accordance with this Law; ensuring free medical care with the use of transplantation; observance of human rights and protection of human dignity in the application of transplantation and the implementation of activities related to transplantation, in the manner prescribed by this Law and other laws of Ukraine; ensuring the proper quality and safety of anatomical materials at all stages of transplantation and transplantation activities; ensuring compliance with the basic principles of transplantation; prevention of illegal use of human anatomical materials; coordination of the activities of executive bodies in the field of transplantation and implementation of activities related to transplantation; creating conditions for conducting scientific research, introduction of new technologies for the use of transplantation and implementation of activities related to transplantation; development of international cooperation in this field. The Cabinet of Ministers of Ukraine, central and local executive bodies shall ensure the formation and implementation of state policy in the field of transplantation and implementation of activities related to transplantation within the limits of their powers" [3]. Further development of transplantology, reform in this area with effective changes, introduction of international best practices, needs support at the national level.

Keywords: state regulation, medical tourism, legal regulation, transplantology.

Постановка проблеми. Звіти 3 досліджень людського розвитку за 
програмою Організації Об'єднаних Націй свідчать про зниження рівня здоров'я населення в Україні, як порівняльний вимір ступеня сталого розвитку країни. Статистичні дані 3 коефіцієнту смертності населення від хвороб системи кровообігу та злоякісних новоутворень невтішні [1]. Збільшуються черги громадян та листи очікування на трансплантацію, які через нестачу донорського матеріалу, коштують пацієнтам життя. Цілісної, побудованої, комплексної та злагодженої системи трансплантології в Україні, на жаль, не існує, потребує уваги недосконала нормативно - правова база, хоча реформа трансплантології на законодавчому рівні відбувається 32019 року. Презумпція згоди та презумпція незгоди на донорство не мають практичного використання. Не працює система ЄДІСТ в повному загальнонаціональному масштабі, в лікувальних закладах не введено констатації смерті мозку людини, недостатній рівень забезпечення такими спеціалістами, як трансплант - координатор у лікувальних закладах, що унеможливлює донорство, а це в свою чергу, не дає розвитку трансплантації. Не створено органу координації донорства на державному рівні. Дуже важливим $\epsilon$ реалізація права на охорону здоров'я, яке закріплено в основному Законі України - Конституції, зокрема у Ст. 49.

Аналіз останніх досліджень і публікацій. Слід зазначити, що питання організаційно - правового характеру та публікації на високому науковому рівні 3 проблематики державного регулювання трансплантологією, зустрічаються у наукових працях, але деякі питання вимагають більш поглибленого дослідження, особливо 3 формування і реалізації регуляторної політики розвитку цього напряму медицини. Відомі праці з цієї проблематики Л. Жаліло, І. Рожкової, М. Білинської, В. Рудима, Я. Радишева та ін.

Мета статті. Висвітлення державного механізму регулювання трансплантологією, правових аспектів в закладах охорони здоров'я, який здійснює діяльність 3 трансплантації, проблем розвитку цього напряму та шляхи удосконалення.

Виклад основного матеріалу. Протягом тривалого часу операції 3 пересадки органів в Україні були винятковими. Більшість громадян, які потребували трансплантації прямували за кордон, займаючись медичним туризмом, зокрема в республіку Білорусь та в Індію. Правила відвідування інших країн, правила транскордонного пересування громадян зазнали значних змін, що пов'язане 3 епідемією захворювання COVID - 19. Отримання послуг 3 діагностики, лікування, протезування та інших видів медичного втручання, реабілітації, оздоровлення за межами постійного проживання - все це належить до медичного туризму [1, с.150]. Реформа трансплантології в Україні почалася в рамках медичної реформи ще в 2019 році з підписання відповідного закону. Виділяють три напрями розвитку трансплантології: трансплантація органів, 
тканин та клітин; в статті приділяється увага органній трансплантології.

Система трансплантології Іспанії націоналізована та централізована. Створена Національна організація 3 трансплантації, яка підпорядковується Міністерству охорони здоров'я Іспанії, відповідає за координацію процесу трансплантації. Ця країна має один з найвищих показників кількості донорів у світі, що обумовлено діючою презумпцією згоди (у разі раптової смерті людина автоматично стає донором, якщо за життя не висловилася проти цього). У США діє, навпаки, інша система та презумпція незгоди (людина за життя має дати згоду на використання органів після смерті, а якщо згоду не надано, можливе отримання від близьких родичів загиблого). Діє заохочення людей на державному рівні до порятунку інших. Об’єднана мережа спільного використання органів неприбуткова організація, що співпрацює 3 волонтерськими i координує на національному рівні процеси трансплантології. У Білорусі діє презумпція згоди, вона входить до десятки країн в світі за обсягами донорства, випереджаючи деякі країни СС, Канаду та Велику Британію. Практичний досвід лікарів, сучасне обладнання, методики, цінова перевага операцій порівняно 3 європейськими клініками - переваги трансплантації органів в Білорусі [5]. В Україні діє і презумпція згоди, i презумпція незгоди на донорство. Однак практичне використання ще потребує уваги та регулювання.

Питання $з$ трансплантологї в Україні регулюються наступними нормативно - правовими актами: Законом України «Про застосування трансплантації анатомічних матеріалів людині» від 17 травня 2018 року зі змінами [3], Законом України «Основи законодавства України про охорону здоров’я» від 19 листопада 1992 року зі змінами [4], Постановою КМУ від 18 грудня 2019 р. № 1083 «Про затвердження переліку послуг та тарифів на послуги 3 надання третинної (високоспеціалізованої) медичної допомоги методом трансплантації органів та інших анатомічних матеріалів, які надаються учасниками пілотного проекту щодо зміни механізму фінансового забезпечення оперативного лікування 3 трансплантації органів та інших анатомічних матеріалів», Наказом МОЗ України від 26 липня 1999 року № 184 “Про затвердження форм облікової статистичної документації, що використовується в стаціонарах лікувально - профілактичних закладів”, Наказом МО3 України від 25.09.2000 р. № 226 Про затвердження нормативно-правових документів 3 питань трансплантації: інструкцією щодо вилучення органів людини в донора-трупа, інструкцією щодо вилучення анатомічних утворень, тканин, їх компонентів та фрагментів у донора-трупа, переліком органів людини, дозволених до вилучення у донора-трупа, переліком анатомічних утворень, тканин, їх компонентів та фрагментів і фетальних матеріалів, дозволених до вилучення у донора-трупа i мертвого плоду людини, інструкцією щодо виготовлення біоімлантатів, умовами забезпечення 
збереження анатомічних матеріалів під час їх перевезення; Наказом МОЗ від 23.09.2013 р. № 821 «Про встановлення діагностичних критеріїв смерті мозку та процедури констатації моменту смерті людини», Наказом МОЗ України від 04.06.2019p. №1246 "Про внесення змін до Довідника кваліфікаційних характеристик професій працівників. Випуск 78 “Охорона здоров”я”, Постановою КМУ № 266 від 29.04.2015 року “Про затвердження переліку галузей знань i спеціальностей за якими здійснюється підготовка здобувачів вищої освіти”, Наказом МОЗ України від 07.02.2020 № 289 «Про внесення змін до Переліку назв циклів спеціалізації та вдосконалення лікарів (провізорів)», Постановою КМУ від 5 серпня 2020 р. № 720 «Про затвердження Порядку перевезення анатомічних матеріалів людини в межах України, ввезення таких матеріалів на митну територію України та вивезення їх за межі митної території України», Постановою КМУ від 27 грудня 2018 р. № 1211 «Деякі питання реалізації Закону України «Про застосування трансплантації анатомічних матеріалів людині»» [6].

Заклади охорони здоров’я отримали на законодавчому рівні фінансування, що надає можливість для розвитку надання цих послуг. Фактично є розподіл медичної допомоги із застосуванням трансплантації (заклади охорони здоров’я повинні мати ліцензію з медичної практики, що передбачає право надання медичної допомоги із застосуванням трансплантації) та здійснення діяльності, пов’язаної з трансплантацією (заклади охорони здоров’я з ліцензією з медичної практики, бюро судово-медичної експертизи та інші суб'єкти господарювання, навіть не заклади охорони здоров’я). Надання медичної допомоги із застосуванням трансплантації - це фактично послуги з трансплантації (пересадка анатомічного матеріалу), які надаються в Центрі трансплантації.

До суб’єктів центрів трансплантації належать: Державна установа “Національний інститут серцево-судинної хірургії імені М. М. Амосова НАМНУ», Державна установа «Національний інститут хірургії та трансплантології імені О.О. Шалімова НАМНУ», КНП “Одеська обласна клінічна лікарня" Одеської обласної ради, м. Одеса, КНП “Київський міський центр нефрології та діалізу" виконавчого органу Київської міської ради (Київської міської державної адміністрації), м. Київ, Державна установа "Інститут серця Міністерства охорони здоров’я України”, м. Київ, КНП Харківської обласної ради “Харківський обласний клінічний центр урології і нефрології ім. В. І. Шаповала”, м. Харків, Комунальна установа «Запорізька обласна клінічна лікарня» Запорізької обласної ради, Комунальний заклад “Дніпропетровська обласна клінічна лікарня ім. І. І. Мечникова”, м. Дніпро, КНП Львівської обласної ради “Львівська обласна клінічна лікарня”, м. Львів, КНП “Вінницька обласна клінічна лікарня ім. М.І. Пирогова Вінницької обласної ради”, м. Вінниця, КНП “Клінічна лікарня швидкої медичної допомоги м. Львова”, м. Львів, КНП “Миколаївська 
обласна клінічна лікарня” Миколаївської обласної ради, м. Миколаїв, КНП Сумської обласної ради “Сумська обласна клінічна лікарня”, м. Суми, КНП “Хмельницька обласна лікарня” Хмельницької обласної ради, м. Хмельницький, КНП “Центральна міська клінічна лікарня Івано-Франківської міської ради”, м. Івано-Франківськ, КНП“Черкаський обласний онкологічний диспансер Черкаської обласної ради", м. Черкаси, КНП Ковельське міськрайонне територіальне медичне об'єднання Ковельської міської ради Волинської області, м. Ковель, КНП “Тернопільська університетська лікарня” Тернопільської обласної ради, м. Тернопіль, Комунальне підприємство “1-А міська клінічна лікарня Полтавської міської ради”, м. Полтава.

$\mathcal{E}$ нормативно - правовий акт, який визначає учасників пілотного проекту 3 трансплантології. Міністерством охорони здоров’я України було виділено кошти для здійснення додаткового фінансування, також розроблена спеціальна програма фінансування діяльності з трансплантології, яка діє з 2018 року. У 2021 році видатки з бюджету України становлять 502 млн. грн. [5]. На підставі укладених контрактів ці заклади можуть отримувати фінансування з MO3 по пілотному проекту. Також закон передбачає, що має бути створений спеціальний орган, який би координував роботу системи трансплантології в Україні, але такий орган не створено, що спонукає до появи низки проблем для закладів охорони здоров’я.

До діяльності, пов’язаної з трансплантацією належать медичні послуги 3 вилучення анатомічних матеріалів у живих донорів; вилучення анатомічних матеріалів у донора-трупа, що здійснюються закладами охорони здоров'я, бюро судово-медичної експертизи або іншими суб'єктами господарювання, що згідно i3 законодавством мають право здійснювати таку діяльність; послуги із зберігання i перевезення анатомічних матеріалів людини, призначених для трансплантації; вилучення анатомічних матеріалів у донора-трупа для виготовлення біоімплантатів, зберігання i перевезення таких матеріалів; трансплант-координації; а також діяльність із забезпечення функціонування інформаційних систем і реєстрів у сфері трансплантації (СДІСТ). Вище зазначене розмежування впливає на розмір фінансування закладу охорони здоров'я. Діяльність пов'язану з трансплантацією здійснюють наступні суб'єкти: бази вилучення анатомічного матеріалу, центри трансплантації, координаційний центр 3 адміністрування ЄДІСТ (Сдиної державної інформаційної системи трансплантації), інші суб’єкти господарювання в частині перевезення анатомічних матеріалів. Не медичні заклади можуть бути долученими до етапів трансплантації, закон розширив коло таких суб’єктів. Координаційний центр, як суб’єкт організації взаємодіє з Центрами трансплантації та базами вилучення. Бюро судово - медичних експертиз на сьогоднішній день - не медичні заклади (лише одиниці мають ліцензію на мед практику). 32021 року запрацював Закон 
про впровадження єдиної державної інформаційної системи трансплантації. Система «Донор - реципієнт» розроблена ще на початку 2019 року, але були деякі неврегульовані аспекти Міністерством охорони здоров’я України, а саме - не було розроблено алгоритму пошуку «донор - реципієнт» - це медичні дані збігу за низкою критеріїв. Не було нормативного розробленого документу, який би визначав збіг вищезазначеної пари. Це одна $з$ причин, за якої робота єдиної державної інформаційної системи трансплантації була неможливою. СДІСТ повинна надавати в автономному режимі лікарням інформацію співпадіння пари «донор - реципієнт», зважаючи на місцезнаходження кожного 3 пари та конкретизувати реципієнта, не торкаючись загальнолюдської проблеми - черги, 3 тієї причини, що людей, які потребують трансплантації в країні багато, але на жаль, конкретної цифри немає. Всі реєстри ведуться безпосередньо в закладах охорони здоров'я, а загальнонаціональної черги в Україні немає. Цю проблему частково вирішує існуючий координаційний центр [6].

Основні документи та дії, якими потрібно керуватися у закладах охорони здоров'я, центрах трансплантації: ліцензія на медичну практику (зокрема трансплантація); автономізування (реорганізація в комунальні некомерційні підприємства та укладання договорів 3 НСЗУ для можливості отримування фінансування); введення посади трансплант - координатора та працевлаштування відповідного фахівця.

Основні документи та дії, якими потрібно керуватися для баз вилучення: ліцензію на медичну практику, до речі, без обов'язкової специфіки про трансплантації; введення як обов'язкової процедури констатації смерті мозку; автономізування (реорганізація в комунальні некомерційні підприємства та укладання договір 3 НСЗУ, щоб мати можливість отримувати фінансування); введення посади трансплант - координатора та працевлаштування відповідного фахівця; перелік медичного оснащення надається в Наказі 2650 від 23.12.2019 року [7], що передбачає відповідність матеріально - технічного оснащення закладу охорони здоров'я, в якому здійснюються операції 3 трансплантації органів та їх частин, а саме операції з трансплантації серця, печінки, нирки. Існують різні бригади - при вилученні тканин та при вилученні органів. База вилучення може бути також i центром трансплантації, закордонна практика свідчить про можливість скоротити час на транспортування органу, перевага надіється саме тим реципієнтам, які знаходяться в тому медичному закладі, де відбувається вилучення органу. Але в Україні ще зарано говорити про комплексну систему трансплантації, поки не буде врегульовано розподіл анатомічного матеріалу з урахуванням віку, віддаленості території та інших аспектів.

На заклад охорони здоров'я, який $є$ учасником пілотного проекту 3 
трансплантації не поширюються Вимоги до надавача послуг 3 медичного обслуговування населення, з яким головними розпорядниками бюджетних коштів укладаються договори про медичне обслуговування населення, затверджені Постановою КМУ від 28 березня 2018 р. № 391 [8], а саме: наявність ліцензії на провадження господарської діяльності з медичної практики, інших дозвільних документів, передбачених законом; наявність у надавача необхідної для надання послуг 3 медичного обслуговування населення (медичних послуг) за договором матеріально-технічної бази, яка відповідає вимогам галузевих стандартів у сфері охорони здоров'я, примірних табелів матеріально-технічного оснащення, затверджених МОЗ. Міністерство охорони здоров'я, як головний розпорядник коштів пілотного проекту, зобов'язаний профінансувати лікарню яка є учасником цього проекту з трансплантації не залежно від того чи відповідає така лікарня Вимогам щодо ліцензії та відповідності матеріально - технічної бази.

В законах про застосування трансплантації анатомічних матеріалів чітко визначено моменти, при яких юридично наступає факт незворотної смерті людини - це смерть головного мозку та біологічна смерть. У ст. 52 Закону України «Основи законодавства України про охорону здоров’я» наголошується: «Медичні працівники зобов'язані надавати медичну допомогу у повному обсязі пацієнту, який знаходиться в невідкладному стані. Активні заходи щодо підтримання життя пацієнта припиняються у разі, якщо стан людини визначається як незворотна смерть. Моментом незворотної смерті людини $\epsilon$ момент смерті іiі головного мозку або іiі біологічна смерть. Смерть мозку визначається при повному i незворотному припиненні всіх його функцій, що реєструється при працюючому серці і штучній вентиляції легень. Констатація смерті мозку людини здійснюється консиліумом лікарів у закладі охорони здоров'я, в якому знаходиться пацієнт, на підставі діагностичних критеріїв смерті мозку людини. За фактом констатації смерті мозку людини консиліум лікарів складає акт, який підписується всіма членами консиліуму та долучається до медичної документації пацієнта. У склад консиліуму лікарів не можуть бути включені лікарі, які беруть участь у вилученні анатомічних матеріалів та їх трансплантації, а також трансплант-координатор закладу охорони здоров’я.

Біологічна смерть людини встановлюється медичним працівником на підставі діагностичних критеріїв біологічної смерті людини (незворотне припинення кровообігу та дихальних функцій, поява ранніх та/або пізніх трупних змін) з внесенням відповідних відомостей до медичної документації пацієнта. У разі встановлення біологічної смерті людини констатація смерті мозку людини не проводиться. Порядок припинення активних заходів щодо підтримання життя пацієнта, порядок констатації та діагностичні критерії смерті мозку людини, положення про консиліум лікарів, форма акта про констатацію смерті мозку 
людини, діагностичні критерії біологічної смерті людини затверджуються центральним органом виконавчої влади, що забезпечує формування державної політики у сфері охорони здоров’я.

Медичним працівникам забороняється здійснення евтаназії - навмисного прискорення смерті або умертвіння невиліковно хворого з метою припинення його страждань» [4].

Процедура трансплантації можлива тільки після констатації смерті мозку. Наказ МОЗ від 09.11.2020 р. № 2559 регулює процедуру констатації смерті мозку людини [9]. Ця процедура починає впроваджуватися в закладах охорони здоров’я, для цього закладу охорони здоров'я необхідно мати консиліум лікарів, який би здійснював таку констатацію. До складу консиліуму лікарів не можуть бут включені лікарі, які беруть участь у вилученні анатомічних матеріалів, які беруть участь у трансплантації цих анатомічних матеріалів, а також трансплант координатор закладу охорони здоров'я. При процедурах констатації смерті мозку: керівник закладу охорони здоров'я щороку призначає наказом особу, відповідальну за призначення складу комісії, нею може бути: заступник керівника 303 або наукової установи; черговий лікар; завідуючий відділенням реанімації (нейрореанімації або інтенсивної терапії), що має досвід роботи більше п’яти років. До складу консиліуму лікарів можуть входити: лікар-анестезіолог, що має досвід практичної роботи не менше п’яти років, та лікар-невропатолог (нейрохірург), що має досвід практичної роботи не менше п’яти років. Консиліум лікарів складає Акт за формою № 012/o, який підписується всіма членами консиліуму та додається до Медичної карти стаціонарного хворого за формою первинної облікової документації № 003/о. При процедурах констатації біологічної смерті людини - лікарська комісія у складі: завідуючого реанімаційним відділенням, лікаря - реаніматолога та лікаря - судово-медичного експерта, складає Акт констатації біологічної смерті за формою №017/о, затвердженою Міністерством охорони здоров'я України. В акті констатації біологічної смерті людини обов'язково повинен фіксуватися час (година, хвилина) констатації біологічної смерті людини. У разі встановлення біологічної смерті людини констатація смерті мозку людини не проводиться. Трансплантація в Україні не матиме розвитку без введення в лікарнях процедури констатації смерті мозку, без донора процедура трансплантації не можлива [6].

При житті кожен громадянин може дати згоду на донорство після смерті, юридична процедура існує, а фактична реалізація ii не можлива. Запроваджується надання такої згоди через цифровий додаток «Дія».

Забороняється вилучення анатомічних матеріалів у разі якщо: є прижиттєва письмова незгода на донорство (в СДІСТ наявні відомості про надану особою прижиттєву письмову незгоду на посмертне донорство); якщо відсутня згода на 
донорство (людина при житті не висловила згоду в ЄДІСТ): відсутність письмової згоди їі повноважного представника, наявність якого встановлено трансплант-координатором згідно з даними ЄДІСТ, відсутності письмової згоди другого з подружжя або одного з близьких родичів (діти, батьки, рідні брати та сестри), або відсутності письмової згоди особи, яка зобов'язалася поховати померлого, відсутності письмової згоди батьків особи віком до 18 років або інших іï законних представників, відсутності осіб, у яких можна взяти згоду (другого з подружжя або одного з близьких родичів (діти, батьки, рідні брати та сестри); або є заборона на вилучення анатомічних матеріалів (заклад охорони здоров'я отримав заборону на вилучення анатомічних матеріалів 3 тіла доноратрупа відповідно до рішення суду або правоохоронних органів, отримання обгрунтованих заперечень судово-медичного експерта на вилучення анатомічних матеріалів 3 тіла донора-трупа за наявності відповідного судового рішення або рішення органу досудового розслідування про проведення судової експертизи). Тут потрібно зауважити, що в останньому випадку експерт має дати не дозвіл, а заперечення, тобто, якщо заперечень немає, то вилучення можливе [6].

Забороняється вилучення анатомічних матеріалів у разі: якщо померла особа належить до наступних категорій: діти-сироти та діти, позбавлені батьківського піклування; особи, визнані в установленому законом порядку недієздатними; особи, особистість яких не встановлена; особи, які загинули в результаті проведення антитерористичної операції та інших бойових діях під час безпосередньої участі у здійсненні заходів із забезпечення національної безпеки і оборони, відсічі і стримування збройної агресії Російської Федерації у Донецькій та Луганській областях, перебуваючи безпосередньо в районах та у період здійснення зазначених заходів, та інших бойових діях [6].

У Ст. 20 Закону про трансплантацію відзначено заборону торгівлі анатомічними матеріалами людини та їх рекламування. Укладання або пропонування укладення договорів, що передбачають купівлю-продаж анатомічних матеріалів людини, забороняються. Реклама анатомічних матеріалів людини забороняється, крім соціальної реклами 3 метою популяризації трансплантації анатомічних матеріалів людини [3]. Донорство є безкоштовним, інакше знецінюється життя людини.

Щодо фінансування медичної послуги 3 трансплантації. В Україні затверджено вартість трансплантації органів. Згідно з Постановою № 1083 від 18 грудня 2019 року, вартість алотрансплантації нирки (від живого донора або донора - трупа) коштує 323798 грн., АВО-несумісна алотрансплантації нирки 721230 грн., трансплантація серця/комплексу “серце-легені” або після перенесеної трансплантації серця/комплексу “серце-легені” - 535280 грн., пересадка печінки/частини печінки - 855039 грн., донорська нефректомія 3 
відкритого доступу - 33561 грн., донорська резекція печінки - 116130 грн., донорський етап - вилучення органів у донора-трупа - 74086 грн., тканинне типування донора (визначення HLA-антигенів методом ПЛР) - 18630 грн., тканинне типування реципієнта (визначення HLA-антигенів методом ПЛР) - 18630 грн., донорський етап - вилучення органів у донора - трупа - 74086 грн. [10].

Як зазначалося, у медичного закладу для отримання фінансування, повинна бути ліцензія на медичну практику, впроваджена обов'язкова процедура констатації смерті мозку, фахівець на посаді трансплант - координатора, контракт з Центром трансплантації щодо наданої послуги з вилучення органів. Вилучення донорських органів оформлюється актом про вилучення органів у донора-трупа для трансплантації за формою 033/о «Акт про вилучення органів i тканин у донора-трупа для трансплантації». За вилучення органу на базі забору сплачує центр трансплантації. Слід зазначити на відсутністі затверджених МO3 порядку розподілу анатомічних матеріалів та критеріїв встановлення пар «донорреципієнт». Кошти з донорського етапу отримує центр трансплантації, а потім має їх відшкодувати тому закладу, де здійснювалося вилучення анатомічних матеріалів.

Перевезення анатомічних матеріалів можуть здійснювати бригади вилучення анатомічних матеріалів, представники закладу охорони здоров'я, представники бюро судово - медичних експертиз, будь - який суб'єкт господарювання. Алгоритм та умови перевезення наступні: 1. Визначення сумісності пари донор реципієнт (з 01 січня 2021 року визначення пари має здійснюватися лише за допомогою ЄДІСТ, до 01.01.2021 - консиліум лікарів), 2 роки поспіль відкладався запуск системи., а ЄДІСТ не працював, тому що не було розроблено в MO3 алгоритму пошуку пари «донор - реципієнт». 2. Укладення контракту на перевезення, в якому дотримання стандартів - це обов’язок перевізника. 3. Перевезення має здійснюватися 3 дотриманням вимог та стандартів визначених MO3 - обов'язкова умови в договорі, але вимог і стандартів немає, лише стерильні ємності (пакети), які розміщені в теплоізолюючих контейнерах, хоча в Директивах Європейського Союзу вони стандарти існують [6].

Трансплант-координатор - працівник закладу охорони здоров'я, бюро судово-медичної експертизи, спеціалізованої державної установи у сфері трансплантації органів, тканин та клітин, іншого суб'єкта господарювання, що здійснює діяльність, пов'язану з трансплантацією, до посадових обов'язків якого належить здійснення трансплант - координації. Не приймаються рішення трансплант - координатором, він лише координує; до його обов'язків входить наступне: виявлення потенційного донора; встановлення факту надання згоди на донорство, пошук та спілкування 3 родичами потенційного донора (таке спілкування розпочинається вже після діагностування смерті мозку); організація 
проведення обстежень потенційного донора; організація вилучення, зберігання i перевезення анатомічних матеріалів; занесення інформації про вилучення органу до СДІСТ, але приймати рішення про вибір реципієнта координатор не може. У разі виникненні обставин, перелік яких визначає MO3 (не визначено), що призвели або можуть призвести до неможливості трансплантації конкретному реципієнту, або створюють ризик незбереження анатомічних матеріалів, трансплант - координатор донора - трупа приймає рішення щодо: порядку проведення вилучення анатомічних матеріалів, вибору реципієнта, проведення трансплантації та здійснення діяльності, пов’язаної 3 трансплантацією; що вимагає уточнень і роз'яснень, тому що це суперечить вищезазначеним обов’язкам координатора. Корупційні схеми можуть бути припинені завдяки системі ЄДІСТ, завдяки автоматизації та відсутності суб'єктивної думки [6].

Права трансплант - координатора: 1. Отримувати соціальні гарантії, передбачені законодавством. 2. Мати доступ до інформації для виконання своїх посадових обов’язків, зокрема право на вхід до ЄДІСТ. 3. Вносити пропозиції щодо покращення роботи ТК. 4. Повідомляти керівництво про будь-які невідповідності, виявлені в процесі діяльності ТК, та вносити пропозиції, щодо їх усунення. 5. Брати участь в заходах, спрямованих на підвищення кваліфікації та свого професійного рівня. У Ст. 9 Закону про трансплантацію йдеться про те, що ТК приймає рішення щодо: порядку проведення вилучення анатомічних матеріалів, вибору реципієнта, проведення трансплантації та здійснення діяльності, пов’язаної з трансплантацією. В обов'язки Трансплант - координатора входить: 1.Виявлення та ідентифікування потенційного донора. 2. Організація проведення обстеження (клінічних та лабораторних досліджень) потенційного донора. 3. Організація заходів щодо констатації смерті мозку. 4. Проведення роз'яснювальної роботи з представниками та/або родичами потенційного донора, щодо надання згоди на донорство. 5. Отримування згоди на донорство, виявлення наявністі згоди (незгоди) на донорство в СДІСТ. 6. Внесення інформації (при наявності згоди) про потенційного донора, про анатомічні матеріали до ЄДІСТ. 7. Організація вилучення, пакування, маркування, зберігання і перевезення АМ. 8. Проведення інформаційно-роз'яснювальної роботи 3 питань трансплантації. Більш детальний перелік обов'язків ТК зазначений в Наказі МОЗ України від 04.06.2019p. №1246 "Про внесення змін до Довідника кваліфікаційних характеристик професій працівників. Випуск 78 “Охорона здоров’я” [11].

Основні кроки для адміністрації лікарні в працевлаштуванні трансплант координатора. Внести зміни до штатного розпису закладу охорони здоров'я 3 метою закріплення нової штатної посади “трансплант-координатор". 15 лютого 2019 року наказом Мінекономрозвитку № 259 було затверджено Зміни № 8 до національного класифікатора ДК 003:2010. В результаті - впроваджено професію 
«трансплант-координатор» у державному Класифікаторі професій за кодом 2229.2. Встановити винагороду- згідно Наказу МОЗ та Мінсоц № 1234/1768 від 12.08.2019 року, який зареєстрований у Мінюсті 27 серпня 2019 р. за № 973/33944, для ТК, трансплант-координаторів паталого- анатомічного бюро (бюро судово-медичної експертизи) встановлено тарифний розряд 13. Розробити посадову інструкцію трансплант-координатора - згідно Наказу МОЗ України від 04.06.2019 року № 1246 “Про внесення змін до Довідника кваліфікаційних характеристик професій працівників. Випуск 78 “Охорони здоров’я” закріплені права та обов'язки трансплант-координаторів. Видати наказ про призначення ТК на посаду - не забороняється суміщення професій. Повідомити уповноважений орган з питань трансплантації про призначення ТК на посаду - СДІСТ передбачає формування спеціального реєстру трансплант-координаторів. Такий реєстр $\epsilon$ відкритим для публічного доступу. Повідомити про призначення ТК Міністерство охорони здоров'я [6].

Слід зазначити позитивні зміни, які відбулися на законодавчому рівні, зокрема: зміна ст. 143 Кримінального кодексу України, що визначає та конкретизує кримінальну відповідальність при умисному порушенні порядку застосування трансплантації, що призводить до тяжких наслідків для потерпілого. До цього моменту будь-якого лікаря, який займався пересадкою органів, можна було притягнути до кримінальної відповідальності, бо попередня редакція статті передбачала кримінальну відповідальність у разі порушення порядку трансплантації, а визначеного порядку не існувало [5, 6].

Листи очікування існують в багатьох державах, завдяки медичному туризму внутрішньому та транскордонному, є надія на спасіння людського життя. Існує безліч етичних проблем, пов'язаних 3 трансплантацією. Не завжди трансплантацію можна розцінювати, як збереження життя громадян України, реципієнтами також можуть бути і громадяни інших держав. Не слід також забувати, що імуносупресивні препарати, які використовуються за кордоном, в нашій державі відсутні; є проблеми фінансування та надмірної політизації цього важливого напряму медицини. Торгівля органами в світі заборонена, низка країн підписали Конвенцію про захист прав людини та основоположних свобод i повинні дотримуватися верховенства міжнародного права.

Висновки. Розвиток такого надзвичайно важливого напряму медицини, як трансплантація, в світі відбувається на загальнодержавному рівні, вона стала одною з успішних медичних практик. Кількість пацієнтів, які потребують допомоги постійно збільшується. Відбувається популяризація донорства на законодавчому рівні, на рівні громадської думки, обізнаності громадян, що рятує життя. Розвиток державного регулювання в сфері трансплантації Україні дасть можливість громадянам врятувати життя і відновити основні функції, коли не 
існує альтернатив лікування. Охорона життя громадян - одне з найважливіших завдань державної політики. Важливим для України є досвід інших провідних держав, оскільки конституційно закріплено курс євроінтеграції та курс до країн північно-атлантичного договору.

\section{Jimepamypa:}

1. Core Health Indicators in the WHO European Region 2020. Special focus: 2030 Sustainable Development Agenda [Електронний peсурс]. - Режим доступу: https://www.euro.who.int/ru/dataand-evidence/evidence-resources/core-health-indicators-in-the-who-european-region/core-healthindicators-in-the-who-european-region-2020.-special-focus-2030-sustainable-development-agenda

2. Регіональний туристичний продукт: проектний підхід до забезпечення конкурентоспроможності : монографія / За заг. ред. М.М. Іжі, К.Д. Бабова, Т.М. Безверхнюк. Одеса : ОРІДУ НАДУ, 2016. - 626 с.

3. Закон України від 17.05.2018 p. «Про застосування трансплантації та інших анатомічних матеріалів людини» [Електронний ресурс]. - Режим доступу: https://zakon.rada.gov.ua/laws/show/2427-19\#Text

4. Закон України «Основи законодавства про охорону здоров'я» [Електронний ресурс]. Режим доступу: https://zakon.rada.gov.ua/laws/show/2801-12\#Text

5. Незалежна аналітична платформа «Вокс Україна» » [Електронний ресурс]. - Режим доступу: https://voxukraine.org/pozhertvuj-organom-vryatuj-zhyttya-blyzhnomu-shho-vidbuvayetsya- izsystemoyu-transplantologiyi-v-ukrayini/

6. Онлайн курс з медичного права, лекція Марії Слободниченко [Електронний ресурс]. Режим доступу: https://www.donets.partners

7. Наказ Міністерства охорони здоров’я України 23.12.2019 № 2650 [Електронний pecypc]. - Режим доступу: https://moz.gov.ua/uploads/3/16151-dn_20191223_2650_dod_1.pdf

8. Постанова КМУ від 28.03.2018 № 391 «Про затвердження вимог до надавача послуг 3 медичного обслуговування населення, з яким головними розпорядниками бюджетних коштів укладаються договори про медичне обслуговування населення» [Електронний ресурс]. - Режим доступу: https://zakon.rada.gov.ua/laws/show/391-2018-п\#Техt

9. Наказ МОЗ від 09.11.2020 № 2559 «Про деякі питання удосконалення роботи відділень анестезіології та інтенсивної терапії закладів охорони здоров'я» [Електронний ресурс]. - Режим доступу: https://zakon.rada.gov.ua/laws/show/z1259-20\#Text

10. П Постанова КМУ від 18.12.2019 № 1083 «Про затвердження переліку послуг та тарифів на послуги з надання третинної (високоспеціалізованої) медичної допомоги методом трансплантації органів та інших анатомічних матеріалів, які надаються учасниками пілотного проекту щодо зміни механізму фінансового забезпечення оперативного лікування 3 трансплантації органів та інших анатомічних матеріалів» [Електронний ресурс]. - Режим доступу: https://zakon.rada.gov.ua/laws/show/1083-2019-п\#Text

11. Наказ МО3 від 04.06.2019 № 1246 «Про внесення змін до Довідника кваліфікаційних характеристик професій працівників. Випуск 78 "Охорона здоров'я"» [Електронний ресурс]. - Режим доступу: https://zakon.rada.gov.ua/rada/show/v1246282-19\#Text

12. Конвенція про захист прав людини та основоположних свобод [Електронний pecypc]. - Режим доступу: https://zakon.rada.gov.ua/laws/show/995_004\#Text 


\section{References:}

1. Core Health Indicators in the WHO European Region 2020. Special focus: 2030 Sustainable Development Agenda [Електронний ресурс]. - Режим доступу: https://www.euro.who.int/ru/dataand-evidence/evidence-resources/core-health-indicators-in-the-who-european-region/core-healthindicators-in-the-who-european-region-2020.-special-focus-2030-sustainable-development-agenda

2. Izhi, M.M., Babova, K.D., Bezverhnjuk, T.M. (2009). Regional'nij turistichnij produkt: proektnij pidhid do zabezpechennja konkurentospromozhnosti [Regional tourism product: a project approach to ensuring competitiveness]. Odesa: ORIDU NADU [in Ukrainian].

3. Zakon Ukrainy « Pro zastosuvannja transplantaciï ta inshih anatomichnih materialiv ljudini» [The Law of Ukraine «On the use of transplantation and other human anatomical materials»]. (n.d.). zakon.rada.gov.ua. Retrieved from https://zakon.rada.gov.ua/laws/show/2427-19\#Text [in Ukrainian].

4. Zakon Ukrainy « Osnovi zakonodavstva pro ohoronu zdorov'ja » [The Law of Ukraine « Fundamentals of health care legislation »]. (n.d.). zakon.rada.gov.ua. Retrieved from https://zakon.rada.gov.ua/laws/show/2801-12\#Text [in Ukrainian].

5. Nezalezhna analitichna platforma «Voks Ukraïna»»[Elektronnij resurs]. - Rezhim dostupu: https://voxukraine.org/pozhertvuj-organom-vryatuj-zhyttya-blyzhnomu-shho-vidbuvayetsyaiz-systemoyu-transplantologiyi-v-ukrayini/

6. Onlajn kurs z medichnogo prava, lekcija Mariï Slobodnichenko [Elektronnij resurs]. Rezhim dostupu: https://www.donets.partnersНаказ Міністерства охорони здоров'я України 23.12.2019 № 2650 [Електронний ресурс]. - Режим доступу: https://moz.gov.ua/uploads/3/16151dn_20191223_2650_dod_1.pdf

7. Nakaz MOZ [The Order of the Ministry of Health]. (n.d.). zakon.rada.gov.ua. Retrieved from https://moz.gov.ua/uploads/3/16151-dn_20191223_2650_dod_1.pdf [in Ukrainian].

8. Postanova KMU «Pro zatverdzhennja vimog do nadavacha poslug $\mathrm{z}$ medichnogo obslugovuvannja naselennja, z jakim golovnimi rozporjadnikami bjudzhetnih koshtiv ukladajut'sja dogovori pro medichne obslugovuvannja naselennja » [The Decree of KMU «About the statement of requirements to the provider of services in medical care of the population with whom the main managers of budgetary funds conclude agreements on medical care of the population»]. (n.d.). zakon.rada.gov.ua. Retrieved from https://zakon.rada.gov.ua/laws/show/391-2018-п\#Text [in Ukrainian].

9. Nakaz MOZ «Pro dejaki pitannja udoskonalennja roboti viddilen' anesteziologiï ta intensivnoï terapiï zakladiv ohoroni zdorov'ja» [The Order of the Ministry of Health «On some issues of improving the work of departments of anesthesiology and intensive care of health care facilities»]. (n.d.). zakon.rada.gov.ua. Retrieved from https://zakon.rada.gov.ua/laws/show/391-2018-n\#Text [in Ukrainian].

10. Postanova KMU «Pro zatverdzhennja pereliku poslug ta tarifiv na poslugi z nadannja tretinnoï (visokospecializovanoï) medichnoï dopomogi metodom transplantaciï organiv ta inshih anatomichnih materialiv, jaki nadajut'sja uchasnikami pilotnogo proektu shhodo zmini mehanizmu finansovogo zabezpechennja operativnogo likuvannja $\mathrm{z}$ transplantaciï organiv ta inshih anatomichnih materialiv» [The Decree of KMU «On approval of the list of services and tariffs for tertiary (highly specialized) medical care by transplantation of organs and other anatomical materials provided by the participants of the pilot project to change the mechanism of financial support for surgical treatment of transplantation of organs and other anatomical materials»]. (n.d.). zakon.rada.gov.ua. Retrieved from https://zakon.rada.gov.ua/laws/show/1083-2019-п\#Text [in Ukrainian].

11. Nakaz MOZ «Pro vnesennja zmin do Dovidnika kvalifikacijnih harakteristik profesij pracivnikiv. Vipusk 78 "Ohorona zdorov'ja"» [The Order of the Ministry of Health «About modification of the Handbook of qualification characteristics of workers' professions. Issue 78 
"Health Care"»]. (n.d.). zakon.rada.gov.ua. Retrieved from https://zakon.rada.gov.ua/rada/show/ v1246282-19\#Text [in Ukrainian].

12. Konvencija pro zahist prav ljudini ta osnovopolozhnih svobod (n.d.). zakon.rada.gov.ua. Retrieved from https://zakon.rada.gov.ua/laws/show/995_004\#Text [in Ukrainian]. 